Article

\title{
Key Indicators to Build Country Resilience
}

\section{Arnoldo Jose de Hoyos Guevara ${ }^{1}$, Valeria Regina Bertoncelo ${ }^{1}$}

${ }^{1}$ Pontifical Catholic University of São Paulo, São Paulo, Brazil; dehoyos@pucsp.br, valrbertoncelo@hotmail.com

Abstract: Building Country Resilience is a long-term process particularly in the hyper connected world we are living today; and depends on good governance and appropriate equilibrium of respect for people, planet and profits as well as avoiding depleting natural resources that end up affecting the biosphere. Hence represent a most needed Learning ability that may be seeing to be related to the process of Sustainable Development. So, this paper seeks to find best practices and a Ranking of Countries that may help as guides to foster Country Resilience. For this purpose, it was developed a World Resilience Index - WRI based on a Statistical Analysis with updated data from 108 Countries divided into 3 Groups: American Countries - AMER (20 Countries), Advanced Economies - AVECO (22 Countries) mostly from Europe and OTHER (66 Countries); and using a set of Synthetic Variables like the Social Progress Index - SPI, the Environmental Performance Index - EPI, and the Sustainable Development Goals Index - SDGI, besides some related to Governance and the World Risk Index - WRI.

Keywords: Resilience, SPI, EPI, SDGI, GOVERNANCE, WRI, Vulnerability, Susceptibility.

\section{Introduction}

We are now living the COVI-19 crisis with great impacts not only regarding Health; but also, environmental and socioeconomical, for which most of the countries were not prepared; and moreover, differently from the Pandemics of previous centuries this Global Crises is more critical in particularly because of problems of timing, that is the need to give a fast return to events like the Pandemic we are living now, the socio-economical that are coming next; and then extreme climate change that is on its way. As a matter of fact we are living in a Globalized Hyper connected World with a complex system dynamic that makes our day-to-day reality more Volatile, Uncertain, Complex and Ambiguous (VUCA); hence we end up running greater Systemic Risks for which we would need to become anticipatorily more Globally Resilient or even Antifragile as recommended by Nassim Nicholas Taleb [1] in the sense of not only resisting Black Swans kind of shocks [2], but even learning from the experience and getting better.

For decades, the concept of resilience appears in research work at several areas of the science and the applied social science. It is commonly understood that resilience refers to the capacity of a system, be it an individual, a forest, a city or an economy, to deal with change and continue to develop. Based on such definition it is possible to fit in other fields of knowledge. Moreover, according to one of the Best references regarding Resilience, the Stockholm Resilience Center [3], resilience refers to build a capacity to deal with unexpected sustainable development changes, including liaisons and ecosystem impacts due to for example overuse of natural resources, overcrowding in urban centers that give rise to system unbalance. In general, the definition of the hard sciences, especially in engineering considers resilience as a kind of elastic memory of a physical body back to its normal state after being subjected to some type of pressure. One may observe that the term was adapted for other purposes, but does not differ from its origin in Latin that is the ability to return to the previous state. Indeed, the concept of resilience has been adapted in diverse areas of science; however, it is still part of several studies of social sciences and applied social sciences trying to find out what is critical for building resilience and understanding of how these factors may be applied.

What is interesting to observe is the fact that the same crises we are living now is also bringing opportunities to join global efforts for a more Collaborative Strategic Alliances seeking the well-being of all and a better care of our Planetary Life System, and no doubt for this purpose we may need to change our Mind Set. Fortunately, this is happening as shown in recent Proposals like the Great Reset of Klaus Schwab form the World Economic Forum -WEF [4] as well as the Economy of Francesco of Pope Francisco [5], and the SPL-DRM Toolkit of the World Bank Group [6].

As a matter of fact, the WEF, also very recently, published its Global Risk Report [7] focusing: Geopolitical Instability, Economic Concerns, Climate Response Shortcomings, Biodiversity Loss Impact, Technological Governance Deficits, Creaking Health Systems; and very in particular what concerns to Environmental threats for the next 10 years.

Seeking ways to Monitor Resilience and looking for best practices this paper considered 108 countries basically divided in 3 Regions: America(AMER), Europe(AVECO) and Other countries from the Rest of the World(OTHER) for which some key Synthetic Indicators like the Social Progress Index(SPI), the Environmental Performance Index (EPI), and the Sustainable Development Goals Index(SDGI) where selected, besides some related to Governance and the World Risk Index(WRI), to find out countries that are doing better today allowing developing a representative Resilience Ranking Index( RESI) that may be used to monitor the process. 


\section{Methodological approach to study countries resilience}

The rereading of notion of resilience held by the exact sciences to the applied human sciences may be as a society is able to survive and return to their status quo following an event or social adversity or exposure to natural hazards. The different readings take the view that the evaluation of resilience requires its measurement for performance evaluation between communities, cities and countries. In much of the research, there is emphasis of the following: the need for good governance, economic and social development, protection, respect for the environment and respect for people and their communities where they live.

Seeking ways to Monitor Resilience and looking for best practices this paper considered 108 countries basically divided in 3 Regions: America (AMER), Europe (AVECO) and Other countries from the Rest of the World (OTHER) for which some key Synthetic Indicators like the Social Progress Index(SPI), the Environmental Performance Index (EPI), and the Sustainable Development Goals Index( SDGI) where selected, besides some related to Governance and the World Risk Index (WRI) to find out countries that are doing better today allowing developing a representative Resilience Ranking Index (RESI) that may be used to monitor the process.

Since Resilience deals basically with overcoming Risks we considered first the World Risk Index (WRI), presented at the World Risk Report 2020, that includes both the risk of Exposure (Natural hazard sphere) as well as Vulnerability (Societal Sphere ); and then we'll seek for best practices that may help to overcome Risks based mostly on Synthetic Indicators selected that seem more relevant for our 108 countries and considering 3 regions: AMER(20), AVECO(22) and OTHERS(66).

World Risk Index (WRI). The United Nations University Institute for an Environmental and Human Security (UN-EHS) define the susceptibility to face extreme events of nature to determine country resilience. Furthermore, appropriates the definition of governance and the connections of social systems to measure the learning ability and its coping capacities in order to reduce the disaster risk of the country or community. The index of risk aversion of natural disasters is the interaction of events such as earthquakes, floods, storms, droughts, sea level rise, and society at risk community. The WRI is basically the product of Exposure (Natural hazard sphere) x Vulnerability (Societal sphere), where Vulnerability is the mean of Susceptibility, Coping Capacity and Adaptive Capacity [8].

-Vulnerability (VULN) considered as the quality of vulnerable or one that is likely to be exposed to physical or moral damage because of its fragility. The concept can be applied to people, social groups and, is associated with its ability to prevent, resist and overcome potential impacts. The ability to adapt, prevent and learning with negative impact of natural hazards are part of the definition of the lack of responsiveness and lack of adaptability. In addition, it refers to the susceptibility of a system, community is exposed to natural disasters and adverse climatic effects caused by social, physical, economic and environmental factors [9], [10], [11], [12]. Adaptability is the ability of individuals and or the collective in responding and shaping the changes in the social-ecological system [13]. The presence of adaptability allows better management of natural hazards and increase resilience. Vulnerability, adaptability has been used in different areas of research with no consensus about the meaning. Mostly of the concept has been approaching theories and concepts of societal subsystem, ecological, natural, or biophysical subsystems [14]; and according to Niel Adger [15]:

"The vulnerability is most often conceptualized as being constituted by components that include exposure to perturbations or external stresses, sensitivity to perturbation, and the capacity to adapt."

-Susceptibility (SUSC) It describes the conditions and structural characteristics of a society in the face of the likelihood of suffering damage from a natural disaster [8].

-Coping Capacity (CC) Natural disasters bring up the capacity of the society, country to mitigate the negative effects of the damage due to natural disasters, or the existence of a pandemic [8].

-Adaptive Capacity (AC) as long-term promotion of structural changes to limit the negative impacts produced by natural disasters and climate change in the future [8].

-Exposure (EXP) refers to the various elements that a particular area, country, society is exposed to natural disastersearthquakes, cyclones, floods, droughts or sea-level rise. Exposure does not necessarily indicate a risk, as opposed to vulnerability [8].

Actually, besides the WRI an important initiative of the United Nations Office for Risk Disaster Reduction developed a roadmap to make communities safer and more resilient to disasters [16].

Social Progress Index (SPI). Is an advanced Synthetic Indicator developed in 2010, inspired on Amartya Sen and developed by M. Porter from Harvard and S. Stern from MIT is based on 54 variables regarding 3 basic aspects of development: Basic 
Human Needs, Foundations of Wellbeing and Opportunity; and in particular measures the well-being of a society by observing social and environmental outcomes, that include wellness (including health, shelter and sanitation), equality, inclusion, sustainability and personal freedom and safety [17].

Environmental Performance Index (EPI). In contrast to other performance indicators EPI, developed at Yale university, based on 32 variables, considers 11 issue categories and already focus on two policy objectives: Environmental Health( $40 \%$ weight) and Ecosystem Vitality(69\% weight) of the total score that valuates countries according to policies protecting ecosystems and human health, including the assessment of the impact of air quality, water and sanitation on the health of people and how protect your assets water, forests, fisheries, biodiversity, climate, energy and agriculture. This indicator presents how each country is balancing the use of natural resources without its depletion and the impacts of economic development, such as disposal of solid waste, ozone depletion among others has public policies set for the equilibrium of balance of its ecosystem, but also the planet Earth [18].

Sustainable Development Goals Index (SDGI). The overall score measures a country's total progress towards achieving all 17 SDGs that include hundreds of variables that may be considered as focusing 5 aspects; People, Planet, Profit, Peace and Partnerships. The score represents the percentage of SDG achievement. Most of the 17 Goals have had a negative impact with the COVID-19 as may be seen by the Sustainable Development Report 2020 [19].

The World Governance Index (WGI). One of the challenges of reducing the vulnerability of countries is through the intervention of state for public risk reduction policies. In fact, puts the concept of good governance for each country, which is able to recognize the vulnerabilities and manages for inclusion, access and sharing of power. In accordance with World Bank, governance is:

"The exercise of power of each country to manage the resources for economic and social development. Therefore, good governance submits to high development of country".

To measure the Quality of Country Governance since 1996 the World Bank developed the WGI that is based on six dimensions of Governance [20]: Voice \& Accountability, Political Stability and Lack of Violence, Government Effectiveness, Regulatory Quality, Rule of Law, and Control of Corruption; of which we'll be considering the following three:

- Voice and Accountability (VOAC) - it is the perception about democracy, or that citizens are free to choose their government, with that, there is freedom of expression, of association and of the press.

- Government Effectiveness (GOVE) - Concerns about the public good and the perception that the individual has on the quality of service to him. Therefore, it is necessary to formulate public policies independent of political parties and the government's credibility to comply with such policies.

- Rule of Law (RLAW) - it is the perception of agents regarding compliance with the rules of society, especially regarding the quality of the execution of contracts, property rights, courts and the likelihood of crimes and violence.

\section{Analysis and results}

The pandemic exposed all countries to an unexpected event in an hyper connected society and their respective countries, where it required rapid adaptive capacity to contain the spread of the virus, developing Resilience. Moreover, as may have been expected, the recent World Risk Index (WRI, 2020) of the UNU-EHS World Risk Report indicates basic Geographic differences among 5 Regions as may be seen in Table.1, and corresponding Figure 1. 


\begin{tabular}{|l|r|r|r|r|r|r|}
\hline WRI & Risk & Exposure & Vuln & Susc & Lack Cop & Lack Adap \\
\hline Worldwide & 6,42 & 13,06 & 46,08 & 24,17 & 75,63 & 38,18 \\
\hline Americas & 7,88 & 16,53 & 45,08 & 24,17 & 73,91 & 35,67 \\
\hline Asia & 5,76 & 11,87 & 45,97 & 23,73 & 76,26 & 38,57 \\
\hline Europe & 3,41 & 11,39 & 31,54 & 16,44 & 58,65 & 21,68 \\
\hline Oceania & 1,47 & 13,06 & 46,08 & 24,17 & 75,63 & 38,18 \\
\hline Africa & 8,89 & 13,56 & 63,79 & 49,5 & 84,65 & 54,79 \\
\hline
\end{tabular}

Table 1. WRI Comparing Medians of 5 Regions

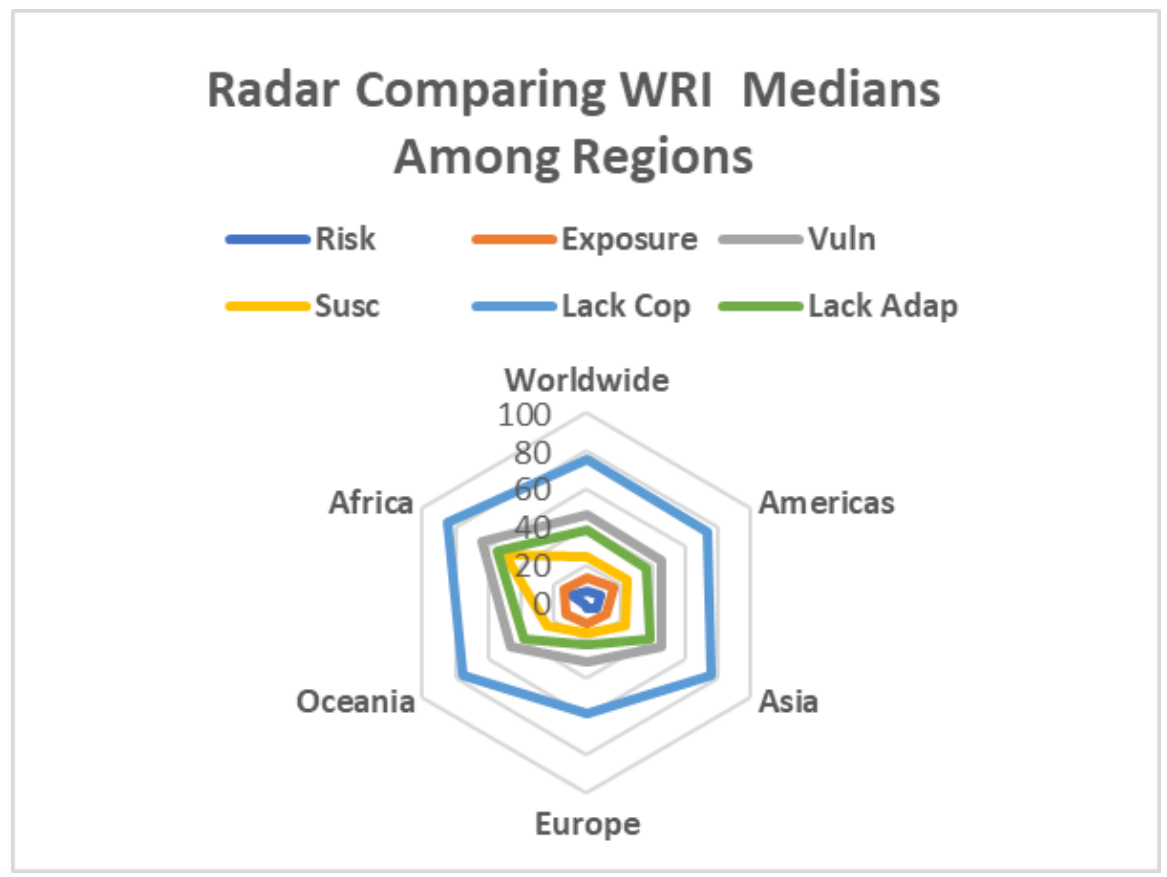

Figure 1. Radar Comparing Risks among 5 Regions

For this purpose, and based in particular on the relationship among variables for the 108 Countries as shown in Table 2 and Fig.2; and the specific relevance for our study, the following 9 variables were selected: the Social Progress Index(SPI), the Environmental Performance Index (EPI), and the Sustainable Development Goals Index( SDGI) besides the World Risk Index(WRI), as well as some more specific of the WRI like SUCEPTIBILITY(SUSC) and Vulnerability(VULN) and some related to GOVERNANCE like Voice and Accountability (VOCACC), Government Effectiveness (GOVEF) and Rule of Law (RULAW).

Based on these 9 selected variables we'll consider the Normalized First Component of a Principal Component Analysis (the only one relevant) as a Resilience Index (RESI) and Table 3 shows the Analysis of Variance of the whole set of Indicators (All Normalized from 0-100, and Positivized) as well as Fig. 4 the corresponding Radar Graph comparing the 3 Regions. As may be seeing the Resilience index (RESI) already calls the attention particularly for the highest differences already present in EPI and Governance. 


\begin{tabular}{|c|c|c|c|c|c|c|c|c|c|}
\hline & RESI & SPI & EPI & SDGI & VOCAC & GOVE & RLAW & WRI & VUL \\
\hline SPI & 0,974 & & & & & & & & \\
\hline EPI & 0,937 & 0,908 & & & & & & & \\
\hline SDGI & 0,903 & 0,904 & 0,838 & & & & & & \\
\hline VOCAC & 0,759 & 0,783 & 0,755 & \begin{tabular}{|l|l}
5 & 0,599
\end{tabular} & & & & & \\
\hline GOVE & 0,914 & 0,86 & 0,828 & 30,729 & 0,72 & & & & \\
\hline RLAW & 0,895 & 0,827 & 0,837 & 0,683 & 0,746 & 0,955 & & & \\
\hline WRI & 0,6 & 0,495 & 0,544 & 0,48 & 0,241 & 0,483 & 0,51 & & \\
\hline VUL & 0,973 & 0,951 & 0,888 & 0,911 & 0,64 & 0,855 & 0,819 & 0,599 & \\
\hline SUCE & 0,833 & 0,833 & 0,695 & 0,859 & 0,41 & 0,665 & 0,596 & 0,51 & 0,909 \\
\hline
\end{tabular}

Table2. Correlations: RESI; SPI; EPI; SDGI; VOCAC; GOVE; RLAW; WRI; VUL; SUCE (all $p<0,000$ )

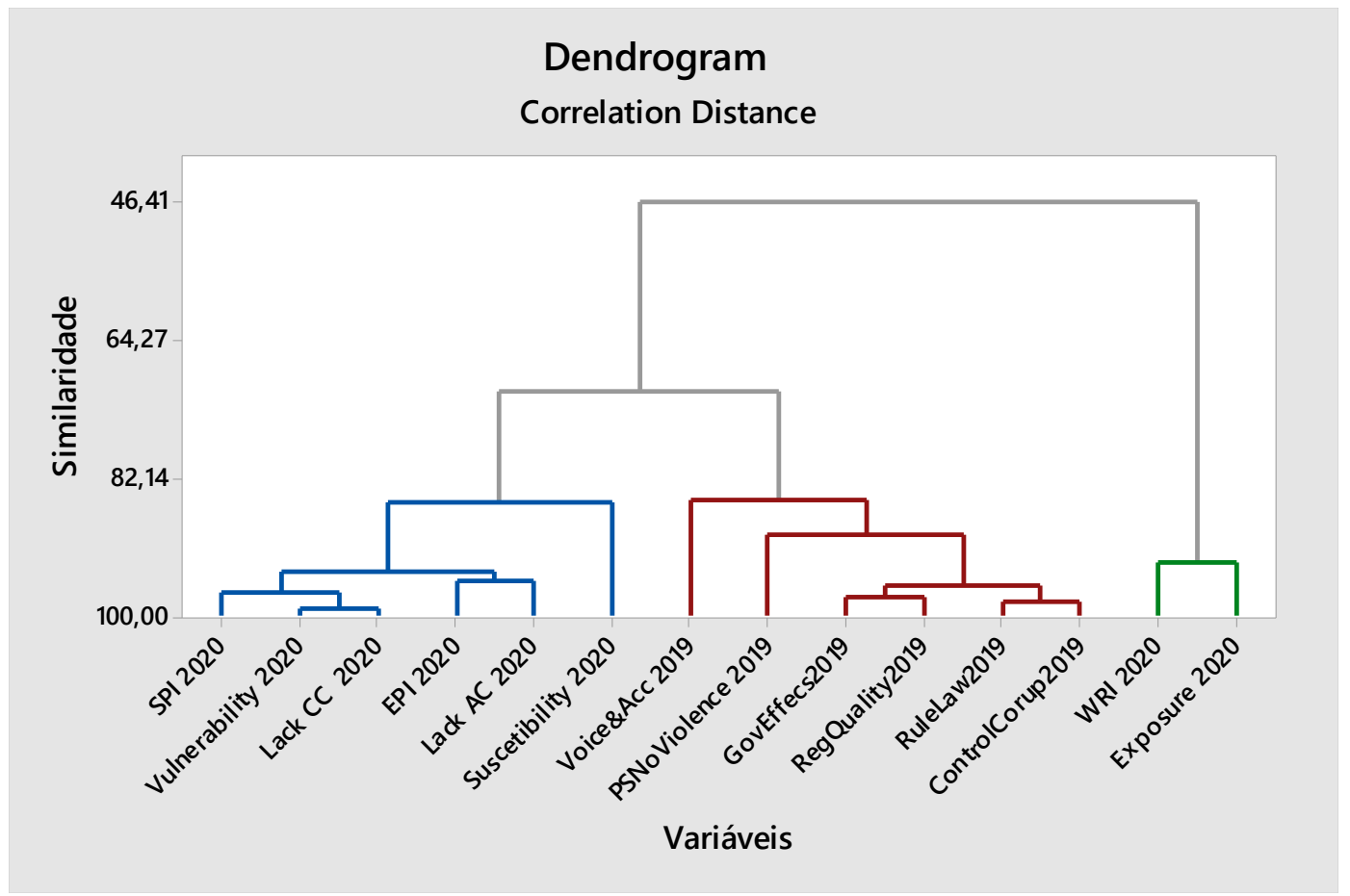

Figure 2. Dendrogram: Correlations graph

\begin{tabular}{|l|r|r|r|r|r|r|r|r|r|r|r|r|r|}
\hline & \multicolumn{1}{l|l|}{ resi } & \multicolumn{1}{l|}{ spi } & \multicolumn{1}{l|}{ epi } & \multicolumn{1}{l|}{ sdgi } & \multicolumn{1}{l|}{ vocacc } & \multicolumn{1}{l|}{ govef } & \multicolumn{1}{l|}{ rulaw } & \multicolumn{1}{l|}{ wri } & \multicolumn{2}{l|}{ vuln } & \multicolumn{1}{l|}{ susc } \\
\hline AMER & 57,72 & 72,01 & 42,45 & 68,07 & 62,86 & 43,6 & 35,35 & 58,69 & 61,34 & 73,02 \\
\hline AVECO & 81,99 & 87,49 & 76,24 & 82,09 & 80,22 & 72,7 & 74,35 & 80,16 & 85,65 & 82,74 \\
\hline OTHER & 49,43 & 60,9 & 34,52 & 57,51 & 45,5 & 42,48 & 37,44 & 69,9 & 55,88 & 64,86 \\
\hline F & 19,38 & 16,26 & 26,06 & 14,49 & 20,39 & 20,58 & 21,22 & 6,5 & 15,09 & 5,34 \\
\hline
\end{tabular}

Table 3. ANOVAS of all the Indicators including the Resilience Index developed 


\section{Comparing 3 Regions}

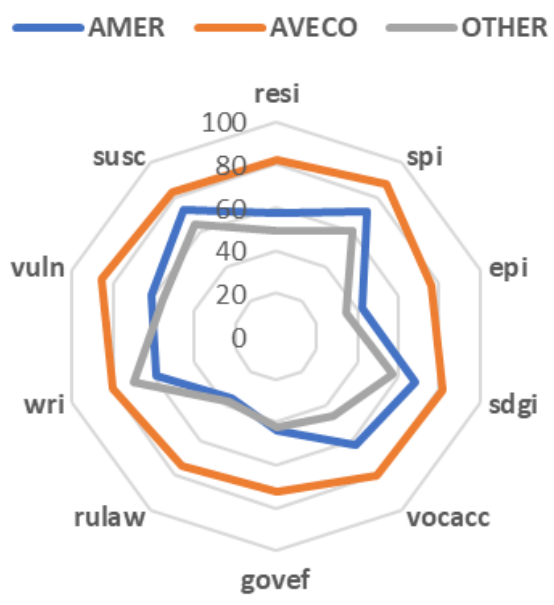

Figure 4. Radar Comparing Means of the 3 Regions

As was to be expected and may be seen in the table and graph, AVECO Countries are doing much better than the other two groups of Countries AMER and OTHER; particularly considering Governance, moreover AMER is in general doing better than OTHER except for the case of WRI.

Finally, regarding the Resilience Ranking (RESI) as may be seen in Table.4, Top 10 Countries are mostly Nordic Countries something also shown by the World Economic Forum Recent Global Competitiveness Report (WEF-SSN) [21], as well as the Bloomberg Covid Resilience (BLOOM-CR) [22]. Table 5 finally shows the whole Ranking of Resilience for the 108 Countries.

\begin{tabular}{rlll}
\multicolumn{1}{l}{ RESI } & WEF-SSN & BLOOM-CR \\
1 Denamark & Denamark & New Zeland \\
2 Finland & Finland & Taiwan \\
3 Sweden & Norway & Australia \\
4 Norway & Austria & Norway \\
5 Switzerland & Luxemburg & Singapore \\
6 Austria & Switzerland & Finland \\
7 Germany & Netherlands & Japan \\
8 Iceland & Spain & South Korea \\
9 Netherlands & Sweden & China \\
10 Canada & France & Denamark
\end{tabular}

Table 4. Top 10 Countries for RESI, WEF-SSN AND BLOOM-CR and the whole list for RESI (Obs.: Prime Minster Women) 


\begin{tabular}{|c|c|c|c|c|c|c|c|c|}
\hline Country & Region & RESI & Country & Region & RESI & Country & Region & RESI \\
\hline Denmark & AVECO & 100 & Bulgaria & OTHER & 68,29 & Morocco & OTHER & 51,15 \\
\hline Finland & AVECO & 99,398 & Romania & OTHER & 67,37 & Dominican Rep. & AMER & 50,98 \\
\hline Sweden & AVECO & 98,507 & Malaysia & OTHER & 65,52 & Iran & OTHER & 48,98 \\
\hline Norway & AVECO & 98,442 & Costa Rica & AMER & 64,98 & Algeria & OTHER & 48,48 \\
\hline Switzerland & AVECO & 98,024 & Mauritius & OTHER & 64,74 & Indonesia & OTHER & 48,40 \\
\hline Austria & AVECO & 95,073 & Argentina & AMER & 64,52 & Vietnam & OTHER & 47,87 \\
\hline Germany & AVECO & 94,498 & Georgia & OTHER & 62,94 & Lebanon & OTHER & 47,87 \\
\hline Iceland & OTHER & 93,132 & Serbia & OTHER & 62,66 & Kyrgyz Rep. & OTHER & 47,78 \\
\hline Netherlands & AVECO & 93,061 & Qatar & OTHER & 62,26 & Egypt & OTHER & 47,06 \\
\hline Canada & AMER & 92,732 & Kuwait & OTHER & 60,90 & Bolivia & AMER & 45,93 \\
\hline New Zealand & AVECO & 91,863 & Armenia & OTHER & 60,22 & El Salvador & AMER & 44,88 \\
\hline France & AVECO & 91,825 & Montenegro & OTHER & 60,14 & India & AVECO & 43,07 \\
\hline UK & AVECO & 91,766 & Brazil & AMER & 59,48 & Ghana & OTHER & 41,30 \\
\hline Australia & AVECO & 90,751 & Ukraine & OTHER & 59,28 & Philippines & OTHER & 40,85 \\
\hline Belgium & AVECO & 90,325 & Bahrain & OTHER & 58,79 & Nepal & OTHER & 38,51 \\
\hline Ireland & OTHER & 89,129 & Panama & AMER & 58,02 & Honduras & AMER & 36,55 \\
\hline Japan & AVECO & 87,57 & Thailand & AVECO & 57,94 & Senegal & OTHER & 36,09 \\
\hline Estonia & OTHER & 86,024 & Colombia & AMER & 57,65 & Tajikistan & AVECO & 35,30 \\
\hline Slovenia & OTHER & 85,955 & Russia & OTHER & 57,36 & Nicaragua & AMER & 33,72 \\
\hline US & AMER & 85,643 & Albania & OTHER & 57,07 & Rwanda & OTHER & 31,43 \\
\hline Czech Rep. & OTHER & 85,352 & Oman & OTHER & 56,81 & Pakistan & OTHER & 30,77 \\
\hline Spain & AVECO & 84,922 & Jordan & OTHER & 56,73 & Kenya & OTHER & 30,28 \\
\hline Portugal & AMER & 84,196 & Kazakhstan & OTHER & 56,62 & Guatemala & AMER & 29,64 \\
\hline Malta & OTHER & 84,11 & Saudi Arabia & OTHER & 56,60 & Bangladesh & OTHER & 29,22 \\
\hline Singapore & OTHER & 82,759 & Mexico & AMER & 56,60 & Cambodia & OTHER & 27,87 \\
\hline Cyprus & OTHER & 80,014 & Bosnia & OTHER & 56,04 & Malawi & OTHER & 25,20 \\
\hline Latvia & OTHER & 79,808 & Jamaica & OTHER & 55,68 & Zambia & OTHER & 25,07 \\
\hline Israel & AVECO & 79,678 & Peru & AMER & 55,10 & Benin & OTHER & 24,91 \\
\hline Slovakia & OTHER & 78,918 & Botswana & OTHER & 54,51 & Uganda & OTHER & 23,46 \\
\hline Italy & AVECO & 78,096 & Ecuador & AMER & 54,39 & Ethiopia & OTHER & 22,62 \\
\hline Poland & OTHER & 77,053 & Turkey & OTHER & 54,35 & Cameroon & OTHER & 20,67 \\
\hline Greece & AVECO & 74,518 & South Africa & AVECO & 53,34 & Mali & OTHER & 18,83 \\
\hline Croatia & OTHER & 74,185 & China & OTHER & 52,59 & Mozambique & OTHER & 18,82 \\
\hline Chile & AMER & 74,083 & Paraguay & AMER & 52,47 & Nigeria & OTHER & 18,31 \\
\hline Hungary & OTHER & 73,545 & Azerbaijan & OTHER & 51,42 & Guinea & OTHER & 17,17 \\
\hline Uruguay & AMER & 69,367 & Mongolia & OTHER & 51,36 & Chad & OTHER & 0,00 \\
\hline
\end{tabular}

Table 5. RSI Country Resilience Rankings

\section{CONCLUSIONS}

The development of resilience of countries, and respectively of their cities, is a hard task for governments, but may help bringing balance and equity for a long-term society. Understanding the importance of good governance in relation to inclusive practices and reducing perception of corruption, may have important impacts on resilience particularly on the most vulnerable countries. The causes of vulnerability may come from different factors, one of them is social aspect i.e. poverty and inequality, marginalization, social exclusion and discrimination; or there is economic dependence due to single industries, globalization of business and its supply chains; or absence of environmental policies, in which is observed poor environmental management, overconsumption of natural resources, decline of risk regulating ecosystem services, climate change etc. As a matter of fact, besides the Sendai Framework for Disaster Risk Reduction of the UNDRR very recently the European Commission adopted its first-ever Strategic Foresight Report that shows the importance of resilience for a strong and lasting recovery, aiming to steer the necessary transitions in a sustainable, fair, and democratic manner [23]. This reinforces the idea that is the most Resilient Region.

Except for the categorized countries of the AIBER, all others have issues related to vulnerability that does not seem to be fully solved. One example is China that has a chain of significant supplies, but no policy on greenhouse gas emissions and the use natural resources; on the other hand, the African continent, except by South Africa, has lack of governance and its population is below the poverty line.

Each country has a different level of social-economic and political development, besides geographical, historical and cultural aspects that permeate the attributes for good governance, that end up having impacts regarding reducing vulnerability and improving resilience.

Fortunately, the present crisis besides the great risks is also bringing hope and awareness that we could do much more joining efforts for a better world for all, not only through the opportunities that may offer the accelerated advances of science and technology at this time like the Data Revolution [24] and the case of Telehealth [25], but also by a transition 
towards a more Caring and Sharing Society that may be already going on; and in particular where Women Leadership is becoming more relevant as may be observed by the fact that half of the Top 10 countries doing best regarding the Resilience Index RESI are on charge of Women Prime Ministers, being the second with the youngest Sanna Marin from Finland (35 years old); and also the Prime Minister of eleventh Top RESI being Jacinda Arden of New Zealand that in fact is considered the country doing best according to the Blooomberg Covid Resilience BLOOM-CR.

\section{References}

1. Taleb, N. N. Antifragile: Things that Gain from Disorder. Penguin, 2013.

2. The Black Swan. Random House, 2nd edition, 2010.

3. SRC Stockholm Resilience Center. Stockholm University. Available in: https://www.stockholmresilience.org/

4. Schwab, K., Malleret, T. COVID-19: The Great Reset. ISBN Agentur Schweiz, 2020.

5. Pope Francis. The Economy of Francesco. In: http://www.vatican.va/content/francesco/en/messages/pontmessages/2020/documents/papa-francesco_20201121_videomessaggio-economy-of-francesco.pdf

6 WBG. SPL-DRM Toolkit. Social protection and labor - Disaster risk management toolkit. World Bank Group, 2020. Available in: https://reliefweb.int/report/world/social-protection-and-labor-disaster-risk-management-toolkit.

7. WEF-World Economic Forum. The Global Risk Report 2020. Available in:

https://www.weforum.org/reports/the-global-risks-report-2020

8. WRI World Risk Index. UNU-EHS World Risk Report, 2020. Available in: http://weltrisikobericht.de/english/

9. Birkmann, J., Buckle, P., Jaeger, J., Pelling, M., Setiadi, N., Garschagen, M., Fernando, N. and Kropp, J. 2010. Extreme events and disasters: A window of opportunity for change? Analysis of changes, formal and informal responses after megadisasters. Natural Hazards. 55(3): 637-669.

10. Birkmann, J., Welle, T., Krause, D. Wolfertz, J., Suarez, D.C. and Setiadi, N. 2011. WorldRisklndex: Concept and results. In: Bündnis Entwicklung Hilft: WorldRiskReport 2011: 13-43.

11. Welle, T., Birgmann, J. The World Risk Index - An Approach to Assess Risk and Vulnerability on a Global Scale. Journal of Extreme Events Volume 2(No. 1), 2015

12 Welle, T., J. Birkmann, J. Rhyner, M. Witting and Wolfertz, J. World Risk Index 2012: Concept, updating and results. In: Bündnis Entwicklung Hilft: WorldRiskReport 2012: 11-27

13. Chapin, F.S., Folke, C., Kofinas, G.P. 2009. A Framework for Understanding Change. In Principles of Ecosystem Stewardship Resilience-based natural resource management in a changing world. Springer, 2009

14. Smit, B., Wendel, J. Adaptation, adaptive capacity and vulnerability. Global Environmental Change, 200616 (3), $282-$ 292.

15. Adger, W.N., 2006. Vulnerability. Global Environmental Change 16 (3), 268-281

16. UNDRR. Sendai Framework for Disaster Risk Reduction 2015-2030, 2015 Available in: https://www.preventionweb.net/files/43291_sendaiframeworkfordrren.pdf

17. SPI. Social Progress Index. Social Progress Imperative, 2020. Available in: www.socialprogress.org

18. EPI. Environmental performance Index 2020. Available in: https://epi.yale.edu/ 
19. SDGI. Sustainable Development Goals Index. Sustainable Development Report 2020. Available in: https://www.sdgindex.org/

20. WGI. World Bank Governance Indicators, 2019. Available in: https://info.worldbank.org/governance/wgi

21. WEF - World Economic forum. How Countries are Performing on the Road to Recovery. Global Competitiveness Report Special Edition, 2020. Available in: https://www.weforum.org/reports/the-global-competitiveness-report-2020

22. Chang, K., Hong, J., Varley, K. The Covid Resilience Ranking. The Best and Worst Places to Be in Covid: U.S. Sinks in Ranking. Bloomberg, 2020. Available in: https://www.bloomberg.com/graphics/covid-resilience-ranking/

23. EU. European Commission-EC. 2020. Commission unveils its First Strategic Foresight Report: Charting the course towards a more Resilient Europe. Available in: https://ec.europa.eu/commission/presscorner/detail/en/ip_20_1586

24. UN-IEAD. A World That Counts. Mobilizing the data revolution for sustainable development, 2014. Available in: https://www.undatarevolution.org/wp-content/uploads/2014/11/A-World-That-Counts.pdf

25. LaRock, Z. The State of Virtual Health in the US. Business Insider, 2020. 